\title{
A SVÉD TANÜGYIGAZGATÁS VÁLTOZÁSAI: EGY RADIKÁLIS MODELLVÁLTÁS
}

\author{
SEMJÉN ANDRÁS
}

MTA KRTK Közgazdaság-tudományi Intézet

\begin{abstract}
A svéd oktatásirányítás az egyik legcentralizáltabb volt Európában, és jó eredményeket ért el a tanulói teljesítmények, az iskolázottság, a foglalkoztatottság és a gazdasági növekedés terén. Idővel azonban kritizálták, hogy nem hatékony, túl drága és nem elég sikeres az egyenlőtlenségek csökkentésében. A kilencvenes évek elején, az akkori neoliberális trenddel összehangban, radikális reformra került sor. Az alap-, középés felső középfokú oktatásért csakúgy, mint a felnőttképzésért minden felelősséget a helyhatóságokra ruháztak, a regionális oktatási tanácsok pedig szerepüket vesztették a központi szándékok továbbításában. Fokozatos finanszírozási reformra is sor került, lehetővé téve az önkormányzatok számára, hogy szabadon allokálják a kormányzattól érkező támogatásokat. Az iskolaválasztás szabaddá vált. A növekvő számú független (a svéd terminológia szerint szabad) iskola éppúgy ingyenes lett a diákok számára, mint az önkormányzati iskolák. Egy oktatási utalványrendszer segítségével a magániskolák is jogosulttá váltak az állami finanszírozásra. Bár fennmaradt a kormányzati elkötelezettség az esélyegyenlőség megőrzésére, az oktatás piacosítását gyakran kritizálják a szegregáció erősödése és a romló tanulói teljesítmények miatt.
\end{abstract}

Kulcsszavakः oktatásirányítás, NPM, decentralizáció, piacosítás, oktatási utalványok

Sweden used to have one of the most centralised education administrations in Europe, and had good results with it concerning academic performance, educational attainment, employment and economic growth. However, the centralised system was criticised for being inefficient and expensive, and not successful in eliminating social inequalities. At the beginning of the nineties, in accordance with the then prevailing neoliberal trends, there came a radical reform. All responsibility for basic, secondary and upper secondary education was given to municipalities, and the regional education boards lost their role in transmitting governmental intentions. There was also a gradual reform of school finance, allowing municipalities to allocate government grants freely. Parents got the right to choose among schools freely. Education remained free for students not only in the public sector, but in the growing independent school sector as well. Free (or inde-

Levelező szerző: Semjén András, MTA KRTK Közgazdaság-tudományi Intézet,

1097 Budapest, Tóth Kálmán u.4.E-mail: semjen.andras@krtk.mta.hu 
pendent) schools became eligible for public funding using a voucher scheme. Although the successive governments wanted to maintain equal opportunities, the marketization of education is often criticised for the increasing signs of segregation and deteriorating student performance.

Keywords education administration, NPM, decentralisation, marketization, vouchers

\section{A kontextus: a svéd közoktatási rendszer pillérei}

A nnak a folyamatnak a jegyében, amit Blossing és Söderstörm (2014) azzal a jelszóval jellemeznek, hogy „egy(séges) iskolát minden gyermeknek”,' az 1960-as években a svéd szociáldemokrata kormány közoktatási reformot vezetett be, mely mind az alapfokú, mind a középfokú oktatásra kiterjedt. Ez a reform az oktatási esélyegyenlőség növelését kívánta szolgálni, és csökkenteni akarta az osztály- és a regionális különbségek hatását az oktatási részvételre és az iskolázottságra. Emellett a reform célja volt még a baby boom hatására megemelkedett létszámú kohorszok középiskola iránti megnövekedett keresletének kielégítése is (Halldén 2008; Erikson-Jonson 1996). E reform keretében 7-től 16 éves korig tartó egységes, kilencosztályos kötelező alapiskolát (grundskola) vezettek be. Eleinte a 7-edik osztálytól fölfelé a választható tárgyak száma viszonylag jelentős volt, ami az egységes jelleget csorbította, ezért 1969-től ezt megszüntették.

1971-ben a középfokot (a svéd terminológia szerint a felső középfokot) is átalakították. Míg addig ezen a szinten három különálló iskolatípus létezett, a szakképző iskola (yrkesskola), az alacsonyabb szintü kétéves szakiskola (fackskola, angol neve continuation school) és a hároméves, felsőfokú továbbtanulásra felkészítő gimnázium (gymnasium), 1971-től már egy egységes komprehenzív középiskolán belül elkülönült tanulmányi programonként léteztek egymás mellett a kétéves szakiskolai, illetve a kétéves szakképző programok és a hároméves gimnáziumi (academic) program. Lehetővé tették a programok közti átjárhatóságot (Olofsson 2005), és bizonyos feltételek teljesülése esetén immár a kétéves középfokú programokból is lehetőség nyílt felsőfokú továbbtanulásra (pl. a munkatapasztalatok beszámításával).

Mint azt Halldén (2008) is idézi, „összességében elmondható, hogy a svédországi iskolarendszer egy meglehetősen hagyományos, korai szelekcióra, több szelekciós pontra és kiskapacitású exkluzív közép- és felsőfokú képzésre épülő európai rendszerből egy olyan rendszerré alakult át, ami meglehetősen hasonló lett a tömeges középiskolázáson alapuló amerikai rendszerhez" (Erikson-Jonsson 1996: 72).

1 Az angol szövegben csak A School for Every Child, illetve A School for All szerepel. Ugyanakkor a kifejtés egyértelművé teszi, hogy itt nemcsak arról van szó, hogy minden gyerek számára biztosítsanak valamilyen oktatást, hanem kimondotta arról, hogy mindannyian egységes, azonos intézményben - azaz egy komprehenziv iskolában, amilyennek például https://en.wikipedia.org/wiki/Education_in_Sweden [letöltve: 2019. 06. 01.] vagy Antikainen 2006 is jellemzik a svéd általános iskolát - tanulhassanak lakóhelyüktől, társadalmi hátterüktől, fizikai vagy szellemi képességeiktől stb. függetlenül. („It expresses a political vision of a school where children shall have an equal education, regardless of their place of residence, social background, physical and mental abilities or other factors that may influence their success in school." Blossing-Söderström 2014: 17.) 
2013-ban a 25-64 éves korú népességen belül a felső középfokú végzettségüek aránya kiemelkedően magas, $87,5 \%$-os volt (OECD 2015). A 2016-os Education at a Glance adatai alapján a fiatalok körében (a 25-34 éves korcsoporton belül) a felső középiskolai végzettségűek aránya ugyan némileg elmarad ettől, $82 \%$ - azonban ez az érték is jónak mondható, a 84\%-os OECD-átlaghoz közeli (OECD 2017). 2011-ben új struktúrát vezettek be a felső középfokon. Ebben 18 ún. nemzeti programból lehet választani, ezek közül 6 a közvetlenül a felsőoktatási továbbtanulásra felkészítő általános program, 12 pedig (immár szintén hároméves) szakképzési orientációjú program (OECD 2015). A felső középfokú továbbtanulás feltétele bizonyos tanulmányi eredmény elérése alsó középfokon: azok részére, akik a kötelező 9 osztály elvégzéséig nem érik ezt el, 5 külön felkészítő bevezető program (introductory programmes) segíti a továbbtanulást vagy a munkaerőpiacra való felkészítést (OECD 2017).

\section{A központosított tanügyigazgatási modelltől a decentralizált tanügyigazgatásig}

Mint azt többek között Lundabl (2002) is megállapítja, a hetvenes évek végéig a svéd oktatáspolitika meghatározása és az oktatásirányítás, tanügyigazgatás rendszere egyértelműen erősen centralizált és szabályozott volt. $\mathrm{Az}$ OECD szerint pedig egészen az 1990-es évek reformjaiig a svéd számított az egyik leginkább centralizált oktatási rendszernek egész Európában (OECD 2015). Ennek a centralizált rendszernek a tanügyigazgatását részletesen tárgyalja magyar nyelven Kádárné (1991).

Ez a centralizált svéd oktatás kétségkívül jelentős eredményeket és sikereket ért el a kompetenciák, az iskolázottság és a fiatalok foglalkoztathatósága terén, és fontos szerepe volt a svéd gazdaság a hetvenes évekig tartó sikertörténetében (Green 1997a, 1997b). A központi oktatáspolitikai szándékok érvényesítését szolgálták többek között a nemzeti tantervek, a címkézett, csak az oktatásra fordítható állami támogatások és a kiterjedt állami szabályozás. Ez utóbbi felölelte az erőforrás-felhasználásra, a szervezeti formákra, a tanárok és egyéb oktatási alkalmazottak foglalkoztatására és az iskolai munka ellenőrzésére vonatkozó részletes központi szabályokat (Lundabl 2002). Az „állam antennáiként funkcionáló" (Daun 2002: 76) regionális oktatási tanácsok (regional educational boards) közvetítették a központi kormányzati elvárásokat az oktatási intézmények felé (Pareliussen 2019).

Ugyanakkor a hetvenes évek végétől kezdve mind a szociáldemokrata, mind a jobbközép kormányzati ciklusok során már egyre inkább érvényesültek azok a tendenciák, melyek először csak a központosított tanügyigazgatás fokozatos eróziójához, majd a kilencvenes években felszámolásához vezettek. A szocialista kormányok már a nyolcvanas években elégedetlenek voltak az oktatás teljesítményével az egyenlőtlenségek csökkentésében, és úgy vélték, hogy helyi szinten, a felhasználókhoz közelebb jobban meg lehet találni azokat a módszereket, amelyek hatékonyabban érik el az egyenlőtlenségek csökkentését. A kilencvenes évek első felében kormányzati pozícióban lévő jobbközép pártok viszont inkább a szokásos neoliberális kritikára (a közösségi szektor - és ezen belül az iskolák - gyenge hatékonyságára, uniformizáltságára és magas költségeire) alapozva érezték feltétlenül szükségesnek a korábbi centralizált rendszer mélyreható reformját (Lundabl 2002). 
A centralizált oktatási rendszert túl költségesnek és nem elég hatékonynak tartó, mind erősebb kritikai hangok, és a dereguláció és decentralizáció irányába mutató nemzetközi közpolitikai trendek, a New Public Management (NPM) irányzatnak a hetvenes évektől kezdődő megerősödése és a kilencvenes évek második feléig tartó uralma (Pollitt-Bouckaert 2011) hatására a kilencvenes években Svédországban több lépésben mélyreható reformokat léptettek életbe, jelentősen átalakítva a svédországi tanügyigazgatást és az oktatásfinanszírozást egyaránt (OECD 2015). 1990-ben a 290 svéd helyhatóságra (helyi önkormányzatra) ruházták a felelősséget az alap- és középfokú oktatásért, illetve a felnőttképzésért. Ezzel párhuzamosan a központosított oktatásirányítás megvalósításában helyi szinten korábban meghatározó szerepet játszó regionális oktatási hatóságok szerepüket vesztették és megszüntek (Daun 2002). A helyi önkormányzatok hatáskörébe került az iskolázással kapcsolatos összes fontosabb döntés, beleértve az oktatás helyének meghatározását, a tanterv megválasztását (a tantervre vonatkozó nemzeti elöírások betartása mellett), a foglalkoztatási döntéseket és az igazgatók kiválasztását. Ezt a későbbi szociáldemokrata miniszterelnök, Gönnar Persson oktatási miniszter által kezdeményezett oktatásirányítási reformot a kisebbségi szociáldemokrata kormány bukása után hatalomra kerülő jobbközép koalíciós kormány hajtotta végre (Rönnberg 2014): ez arra utal, hogy a nagyobb pártokon átívelő egyetértés volt a reform szükségességét és fö céljait illetően.

Annak ellenére, hogy a tanárok az önkormányzatok alkalmazásában álltak, egészen 1996-ig bérüket még a központi bérmegállapodások keretében központilag határozták meg. 1996-ban azonban ez is megváltozott, ekkortól kezdve már a munkafeltételekre és a bérekre vonatkozó munkaügyi megállapodások megkötése is átkerült a központi szintről a helyhatósági szintre.

Ebben a decentralizált tanügyigazgatási rendszerben a központra, az Oktatási és Kutatási Minisztériumra tulajdonképpen csak a nemzeti oktatási célkitűzések meghatározása és az oktatási rendszer eredményeinek értékelése hárul. A központilag kitüzött oktatási célok megvalósításához szükséges eszközökről való döntések már helyhatósági és iskolai szintre vannak telepítve.

A Minisztérium munkáját három (illetve négy) kormányzati ügynökség is segíti (OECD 2015). Az 1991-ben létrehozott Nemzeti Oktatási Ügynökség (Skolverket, hivatalos angol nevén National Agency for Education - a továbbiakban NOÜ) eredeti feladata elsősorban az oktatási reformmal kapcsolatos általános információk terjesztése volt, nem foglalkozott az egyes iskolákat érintő konkrét ügyekkel. Idővel funkciói és feladatai némileg kibővültek. Ezek közé tartozik ma már javaslatok kidolgozása a tantervben szereplő nemzeti oktatási célokra (e célok elérésére kell azután a helyhatóságoknak és az iskoláknak törekedniük), illetve az iskolarendszerre vonatkozó adatok gyüjtése, elemzése és terjesztése, valamint az oktatási célok megvalósulásának nyomon követése és értékelése, továbbá a rendszer különböző szintjeit támogató anyagok kidolgozása.

A másik fontos ügynökség a 2008-ban felállított Svéd Tanfelügyelet, amely az öszszes helyhatósági oktatási intézményt rendszeresen ellenőrzi kilenc regionális egységén keresztül. A látogatások eredményeire, továbbá a NOÜ által biztosított adatokra építve kvalitatív visszacsatolást nyújt a vizsgált intézményeknek.

A tanfelügyelet intézménye a 19. század közepe óta jelen volt a svéd oktatási rendszerben (Rönnberg 2014): mintegy két évtizeddel a kötelező elemi iskolai oktatás bevezetése után, már 1861-ben létrejött az elemi iskolai tanfelügyelet (Folkskoleinspektionen). 
Ekkoriban az elemi oktatást még alapvetően a helyi papok szervezték, és a felügyeletet is föleg papok és elemi iskolai tanítók biztosították. A kormányzat a tanfelügyelet segítségével akarta homogénebbé, egyenletesebb színvonalúvá tenni az elemi iskolai oktatást. A kezdetektől megpróbálták szabályozni és standardizálni a felügyelet munkáját. Ennek visszahatásaképp a tanítók/tanárok már a 19. század végén szakszervezetbe tömörülve próbáltak fellépni a túlzott egyházi befolyás és a túlzottan szabályozott, standardizált felügyelet ellen.

A felügyelet megszervezéséért és lebonyolításáért az idők során különböző, de általában meglehetősen autonóm kormányzati ügynökségek feleltek. 1918 és 1991 között lényegében egy, az oktatásirányításért felelős korporatív ügynökség, az ún. Svéd Nemzeti Oktatási Tanács (Skolöverstyrelsen, SÖ) feladata volt a tanfelügyelet megszervezése és lebonyolítása (Rönnberg 2014). 1958-ban az SÖ szervezetén belül létrejöttek a megyei oktatási tanácsok (Länsskolnämnder), és egyben megszűnt az egyház formalizált képviselete az oktatásirányításban. Ezután a tanfelügyelet megszervezése és lebonyolítása is a megyei oktatási tanácsok feladatává vált.

1991-ben a decentralizációs reform fontos részeként „a hagyományosan a bürokratikus és nem hatékony állami irányítás reprezentánsának tekintett" (Rönnberg 2014: 40) Nemzeti Oktatási Tanácsot (SÖ) felszámolták, és az oktatásirányításért felelős új ügynökség, a NOÜ létrejöttével tíz hosszú évre maga a központi tanfelügyeleti tevékenység is megszünt. A NOÜ létrejöttével a részletes állami szabályozást az oktatáspolitikai célok alapján történő irányítás stratégiája váltotta fel. A decentralizált oktatásirányítási rendszerben a nemzeti szintű irányításnak „kartávolságra” kellett tartania magát az iskoláktól, elegendő manőverezési teret biztosítva a helyhatóságok számára. A NOÜ általános szabályként nem vizsgálhatta az iskolák működését: azonban az újonnan létrehozott, ún. szabad iskolák esetében ellenőrizhette a vonatkozó jogszabályok betartását. Emellett a NOÜ-nek joga volt az egyes iskolák vagy helyhatóságok ellen benyújtott, a közoktatást érintő panaszok kivizsgálására: az ilyen panaszok azonban nem voltak gyakoriak, és kivizsgálásuk nem járt iskolalátogatással.

A központi tanfelügylet felszámolása után elvben a fenntartó önkormányzatokra hárult iskoláik minőségbiztosítása és felügyelete, „és - a politikai színteret domináló decentralizáló politikai retorika irányvonalának megfelelően - nem voltak központi jogszabályok vagy elöírások arra nézve, hogyan lássák el felügyeleti teendőiket. [...] jó okunk van feltételezni, hogy módszereik nagyon különbözőek voltak, és hogy például a falusias területeken lévő kis önkormányzatoknak csak nagyon korlátozott kapacitásuk volt az ilyen feladatok ellátására" (Rönnberg 2014: 40).

Nem kellett azonban sok időnek eltelnie ahhoz, hogy mind a kormányoldalon, mind pedig az ellenzék részéről megfogalmazódjon a tanfelügyelet visszaállításának igénye: már 1994-ben voltak erre irányuló parlamenti kezdeményezések, 1998-tól pedig a NOÜ megkezdte az önkormányzatok oktatási tevékenységének időről időre történő értékelését. 2003-tól újra létrejött a tanfelügyeleti rendszer. A NOÜ két ügynökségre hasadt szét, és a megreformált „maradék” NOÜ fontos feladata lett az önkormányzatok oktatási munkájának vizsgálata és értékelése mellett immár az állami iskolák iskolalátogatások segítségével megvalósuló felügyelete is. 2006 után a jobbközép koalíció hatalomra kerülésével felerősödött a politikai igény a tanfelügyeleti munka intenzívebbé tételére, rövidebb ellenőrzési ciklusokkal és több erőforrással. 2008 októberében önálló ügynökségként létrejött a Svéd Tanfelügyelet. Míg a 2003 utáni NOÜ-ellenőrzések megközelítése „lágyabb” volt, 
elsősorban az iskolai munka javítására, fejlesztésére irányult, az új Tanfelügyelet ellenőrzései már egységes formátumban vizsgálták a formalizált követelmények betartását és a tanulói teljesítmények javulását (Rönnberg 2014).

$\mathrm{A} z$, hogy a decentralizáció következtében megerősödött az igény a központi kontrollra, az ellenőrzésre, a felügyeletre, bizonyos szempontból várható fejlemény volt: a központi hatalom delegálása és a felelősség alacsonyabb szintre való telepítése sokszor jár együtt a központi ellenőrzés fokozódásával (Laegreid-Roness-Rubecksen 2008).

A sajátos nevelési igényü tanulók oktatásával foglalkozó Sajátos Nevelési Igényü Tanulók Oktatási Ügynöksége 1996 óta létezik, és mint azt neve is kifejezi, az SNI-s tanulókat érintő kormányzati törekvéseket hangolja össze. Ezek mellett 1981 óta a Számi Iskolatanács segíti a számi (lapp) iskolákat feladataik teljesítésében, többek között tananyagfejlesztéssel is.

\section{A finanszírozási modell átalakulása}

A decentralizációval párhuzamosan természetesen a finanszírozási rendszert is meg kellett változtatni: az a változás a helyi önkormányzatokra testálta a közoktatásban részt vevő iskolák vonatkozásában a "teljes körű pénzügyi felelősséget” (Björklund et al. 2004, idézi OECD 2015: 46). 1990-et megelőzően a központi kormányzat határozta meg az egyes iskolák számára a felhasználható források nagyságát és belső kiadási szerkezetét. A tanügyigazgatás decentralizálása után a közoktatás finanszírozására szánt központi költségvetési támogatásokat eleinte még címkézett (azaz csak az oktatásra fordítható) átalánytámogatások formájában juttatta el a központi költségvetés az önkormányzatokhoz, de ez hamarosan megváltozott. A címkézett támogatások súlya lecsökkent, majd ezek meg is szüntek, és 1993-tól már a központi költségvetésből származó összes (korábban oktatási célú felhasználáshoz kötött) támogatás az önkormányzatoknak nyújtott egységes általános költségvetési támogatás részeként érkezett az egyes önkormányzatokhoz. Az önkormányzat ezután már szabadon dönthetett arról, hogy a költségvetési támogatás mekkora részét költi oktatásra, és mekkora részt költ egyéb funkcióira, pl. szociális szolgáltatásokra, hulladékgyüjtésre, közegészségügyre stb. (Blanchenay-Burns-Koester 2014).

Mint arra Ablin és Mörk (2007) felhívják a figyelmet, egy ilyen fiskális decentralizáció helyi szinten óhatatlanul a fajlagos finanszírozási kapacitások eltéréseihez vezet, hiszen az önkormányzatok pénzügyi lehetőségei, bevételei eltérőek, és nemcsak a központi költségvetési transzferek mértékétől függenek. Mivel Svédországban továbbra is nemzeti cél maradt az oktatási esélyegyenlőség, ennek biztosításához nyilvánvalóan valamiféle központi beavatkozásra is szükség van. Ugyanakkor ennek a központi beavatkozásnak nem szabad szükségtelen mértékben rontania a közszolgáltatások biztosításának hatékonyságán és az elszámoltathatóságon. A mai svéd közoktatás decentralizált feltételei között a tanulók magas színvonalú kötelező oktatáshoz való egyenlő hozzáférését egyfelől a „központi tanterv és a tantárgyankénti minimális óraszámok központi szabályozása” van hivatva biztosítani, másfelől egy „ambiciózus kiegyenlítő támogatási program, amely a kedvezőtlen feltételek között működő önkormányzatok kompenzálására lett kialakítva" (Ablin-Mörk 2007: 2). 


\section{A decentralizáció megítélése}

Ablin és Mörk (2007) azt vizsgálták, hogy a svéd tanügyigazgatás és iskolafinanszírozás decentralizációja hogyan hatott az iskolák közti erőforrás-allokációra. Munkájuk során a tanár-diák arányok és az egy tanulóra jutó fajlagos kiadások szóródását és egyenlőtlenségének alakulását vizsgálták a reform első pár évében. Az adatok vizsgálata azt mutatta, hogy míg a tanár-diák arányok szóródása csökkent a decentralizációs reform életbe lépése után, az egy tanulóra jutó kiadások tekintetében nem volt egyértelmű hatás kimutatható. Ezek az eredmények ugyan a szerzők szerint egyfelől ellentmondanak mind a chilei, mind pedig az amerikai tapasztalatoknak, másfelől pedig annak is, amit a fiskális föderalizmus elmélete ${ }^{2}$ sugall (Ablin-Mörk 2007: 25), egybevágnak viszont Björklund és szerzőtársai (2004) megállapításaival. A szerzők által a szóródás a decentralizáció utáni csökkenésére kínált magyarázat szerint ez a szereplők stratégiai viselkedésének a következménye is lehet: tekintve, hogy a helyi politikusok tudják, hogy választóik a jövőben felelősségre vonhatják őket a decentralizáció utáni erőforrás-allokációs döntéseikért, törekedhetnek arra, hogy minél kevésbé térjenek el a szomszédos önkormányzatokban megfigyelhető eredményektől.

Regressziós elemzéssel kísérelték meg annak vizsgálatát, hogy a helyhatósági saját jövedelem (adóalap) nagysága hatott-e a decentralizációt követően az iskolai erőforrás-allokációra: sokan tartottak attól ugyanis, hogy a szegényebb önkormányzatokban élő tanulók rosszul fognak járni (kevesebb oktatási erőforráshoz jutnak majd hozzá) a reform következtében. Azt tapasztalták, hogy a felhasznált fajlagos oktatási erőforrások (kiadások) nagysága tekintetében a helyi adóalap nagysága semmivel nem játszik nagyobb szerepet a decentralizációt követően, mint annak előtte. A tanár-diák arányok vizsgálata pedig azt mutatta, hogy közvetlenül a decentralizáció után az adóalap nagyságának ezekre gyakorolt hatása valamelyest kisebb lett, mint annak elötte volt. A z 1993-as önkormányzati támogatási reform (a címkézett támogatások megszüntetése és egyösszegü támogatással történő felváltása) után pedig már nem mutatható ki, hogy az adóalap nagyságának bármi szerepe lenne a tanár-diák arány meghatározásában. Röviden tehát azt mondhatjuk, hogy a szerzők nem találtak bizonyítékot arra nézve, hogy a lakóhely a decentralizációt követően jobban meghatározná az iskolai erőforrásokból történő részesedést, mint annak elötte.

Ahlin és Mörk azt is megvizsgálták, hogy az önkormányzatoknak folyósított központi költségvetési támogatások fajtája (címkézett, célzott/kötött felhasználású, kontra egyösszegű, szabadon felhasználható) mennyire hat az oktatási erőforrás-felhasználásra. A tanulónkénti fajlagos kiadások tekintetében nem találtak ilyen kimutatható hatást; ugyanakkor a tanár-diák arányok esetében azt tapasztalták, hogy minél kevésbé célzottak a támogatások, annál kevésbé költik azokat tanárbérekre. Egy további érdekes eredményük, hogy a központi támogatások időleges (1993-95 közötti) visszaesése nem volt statisztikailag szignifikáns hatással sem a tanár-diák arányok, sem pedig a fajlagos erőforrás-felhasználások nagyságára. Ennek az lehetett a magyarázata szerintük, hogy

Ebbe az (állam különböző szintjei közti optimális munkamegosztással foglalkozó) elméletbe jó betekintést nyújt a magyar olvasóknak Szalai (2002). „A fiskális föderalizmus kiindulópontja egyértelműen a feladatok decentralizálásának vagy centralizálásának kérdése. Milyen szolgáltatások nyújtását kell valamely alsóbb szintü kormányzat kezébe adni, és melyek tartandók meg központi, magasabb szinten?” (Szalai 2002: 425.) 
a helyhatóságok aszimmetrikusan reagálnak a központi támogatások nagyságának változásaira: a központi támogatás átmeneti csökkenése esetén többet költenek saját forrásaikból oktatásra, növekedése esetén pedig kevésbé mélyen nyúlnak a zsebükbe.

Természtesen a decentralizáció megítélését nem csupán az eddig említett finanszírozási következmények befolyásolják. Egy ilyen folyamatnak nyilvánvalóan komoly következményei lehetnek többek között a tanári munkára és az azzal való elégedettségre, a tanulói teljesítményekre, az oktatás minőségére stb. is. Nilsson Lindström és Beach (2015) a tanárok munkaterhelésének növekedését, munkájuk kedvezőtlen irányú átalakulását és munkájukkal való elégedettségük csökkenését hangsúlyozzák az elszámoltathatóságnak a reform következtében bekövetkező erősödése és a növekvő bürokratikus kontroll hatására. Lundahl (2002) a svéd oktatásirányítás és oktatáspolitika befolyásos szereplőivel készített interjúkra épülő tanulmányában elsősorban a szabályok alapján történő irányításról (governance by rules) a célok alapján történő irányításra (governance by objectives) való átállás fontosságát és következményeit hangsúlyozza. Interjúalanyai közül többen is az egységes sztenderdek esetleges erózióját, fenntartásuk nehézségeit említették (Lundabl 2002: 631). Az iskolára gyakorolt szülői befolyás és az elszámoltathatóság erősödését is többen a decentralizációval hozzák összefüggésbe. Az interjúalanyok kisebbik része említette csak a reform negatív következményei között a társadalmi különbségek növekedését. Ugyanakkor a megkérdezettek kritikus hozzáállásuk ellenére pártállásuktól függetlenül mindannyian elismerték, hogy a decentralizáció szükséges volt, és nem tartanák sem lehetségesnek, sem kívánatosnak a korábbi tanügyigazgatási rendszer visszaállítását. Mivel az irányítási decentralizáció mellett, azzal párhuzamosan egyéb változások (pl. az oktatásnak a következőkben tárgyalandó piacosítása irányába történő jelentős elmozdulás) is történtek, az egyidőben bekövetkező változások következményeinek elkülönítése, szétválasztása sok esetben gyakorlatilag lehetetlen.

\section{Lépések az oktatás piacosítása irányába}

Lundabl (2002) rámutat arra, hogy az 1970-es évek végén elinduló, a centralizált tanügyigazgatást fokozatosan átalakító politikai filozófia és kormányzati stratégia, melyre leegyszerüsítő módon általában a decentralizáció és dereguláció címkéit ragasztják, valójában egyidejüleg jelentett elmozdulást a központi irányítástól, az univerzalizmustól, a kormányzati társadalmi tervezéstől és a konszenzusra való törekvéstől a decentralizáció, a partikularizmus és a polarizáció erősödése irányába. Ennek az átalakulásnak a piac és a gazdasági szemlélet alkotta a fö strukturáló elvét. Az ennek az elvnek a jegyében bekövetkező változások számos olyan döntésben nyilvánultak meg, melyek a központi célok megvalósításához kiválasztott módszerek tekintetében a helyi felelősség és a szabadság jelentős növekedésével jártak, főleg a „szakmabeliek” (tanárok, iskolai vezetők) számára. Az oktatásügyi változásokat e folyamat során nagymértékben helyi szinten kezdeményezték, tervezték és valósították meg. Az 1991-94 közötti koalíciós kormányban lévő jobbközép pártok (a mérsékeltek, a centrumpártiak, a liberálisok és a kereszténydemokraták) e folyamat során sokkal nagyobb lépéseket tettek a helyi autonómia erősítése irányába, mint a szociáldemokraták bármikor a korábbiakban. A címkézett támogatások felváltása egyösszegü átalánytámogatásokkal éppúgy ebbe 
az irányba mutató jelentős reformlépés volt, mint az alábbiakban bemutatásra kerülő változtatások.

Mint arra OECD (2015) rávilágít, a tanügyigazgatási és finanszírozási decentralizációval egyidejűleg két másik nagyhatású kormányzati lépés is jelentősen átalakította a közoktatás müködési feltételeit. Az első liberalizációs lépés a (korábban csak kivételes esetekben elérhető) szabad iskolaválasztás általános bevezetése és széles körű elterjedése volt. Ennek hatására mind több tanuló választotta azt, hogy nem a körzeti iskolába iratkozik be. Ahhoz pedig, hogy ez a választási lehetőség mind többek számára vonzó legyen, nagyban hozzájárult az oktatási piac liberalizálása: a jobbközép koalíciós Bildtkormány 1991-es hatalomra kerülése után jelentősen megkönnyítették az ún. független vagy szabad iskolák (azaz a nem állami, nem önkormányzati iskolák) alapítását és müködtetését.

Az ehhez kapcsolódó ún. utalványfinanszírozási (voucher) modell 1992-es életbe lépése óta gyakorlatilag bárki alapíthat és közpénzen müködtethet ilyen iskolát, amenynyiben betartja a vonatkozó kormányzati elöírásokat (Sablberg 2010; OECD 2015). A független iskolákat mindazonáltal engedélyeztetni kell a NOÜ-vel, követniük kell a nemzeti tantervet, továbbá nem szabad képesség, szocioökonómiai helyzet vagy etnikai hovatartozás alapján válogatniuk a jelentkezők közül. Amennyiben az iskola megfelel a korábban említett, központilag elöírt kormányzati szabályoknak, elöírásoknak, a kötelező oktatás a független iskolák tanulói számára is ingyenes és teljes egészében közösségileg finanszírozott, azaz tandíjmentes marad. Ugyanakkor az elöírt feltételeknek megfelelő független iskolák teljes szabadságot élveznek a számukra biztosított közösségi források felhasználását illetően, azaz szabadon határozhatják meg kiadásaik szerkezetét. Szerveződhetnek for-profit és nonprofit alapon is, de mivel a voucher öszszege feletti kiegészítő pénzbeli hozzájárulást vagy tandíjat (top-up fees) tilos kérniük, bevételük és esetleges profitjuk az utalványokból származhat csak.

$\mathrm{A} z$ utalvány nagysága meg kell, hogy feleljen az oktatás átlagos tanulónkénti fajlagos költségének abban az önkormányzatban, amelyben az iskola található. Mind a helyhatósági, mind pedig az államilag támogatott független iskolák a tanulók lakóhelyének megfelelö önkormányzat által fizetett tanulónkénti támogatásból és az egyéb állami támogatásokból szerezhetik bevételeiket (OECD 2015; Eurydice 2018). A fajlagos, tanulónkénti önkormányzati támogatás gyakorlatilag úgy viselkedik, mint egy oktatási utalvány, amelyet a tanuló „magával visz” abba az iskolába, ahová beiratkozik.

Az utalvány nagysága ugyanakkor nem kell, hogy minden tanuló számára egységes legyen, mivel egyfelől a különböző önkormányzatokban ugyanazon iskolatípuson belül is eltérhetnek egymástól a fajlagos oktatási költségek, másfelől iskolatípusok szerint is lehetnek eltérések a fajlagos oktatási költségekben - és így az utalvány értékében is (OECD 2015). Az önkormányzat az oktatási utalvány elve szerint köteles finanszírozni a területén lakó, de nem körzeti iskolájukat választó tanulók képzési költségeit, melyek a fentiek értelmében esetenként akár meg is haladhatják az adott önkormányzatban az adott iskolatípusra egyébként érvényes tanulónkénti átlagos képzési költségeket. Azonban az, hogy a tanulók az önkormányzat határain túl lévő iskolát választanak, inkább csak felső középiskolai szinten fordul elő: ezen a szinten az ország összes középiskolájába szabadon lehet jelentkezni.

Ezeknek a reformoknak betudhatóan az a rendszer, melyben a tanulók kevés kivételtől eltekintve körzeti iskolájukban tanultak, olyanná alakult át, amelyben meglehetősen 
sok tanuló választ más iskolát, mint ami számára alapesetben járna (Edmark-FrölichWondratschek 2014). Míg a reform előtt a kötelező alapoktatásban a tanulók kevesebb mint 1\%-a járt csak független iskolába, 2010-ben az alapoktatás tanulóinak mintegy $10 \%$-a tanult már független iskolában, a felső középfokú képzésben pedig a független iskolában tanuló diákok részaránya a 20\%-ot is meghaladta (Sablberg 2010). Bár továbbra is a közösségi iskolák alkotják az oktatási intézmények többségét, a független magániskolák száma az 1990-es évek eleje óta gyors ütemben bővült. A csaknem 5000 kötelező alapiskola mintegy 16\%-át teszik ki a független iskolák a 2012/13-as tanévben. $\mathrm{Az}$ egyes településeken a független iskolákat látogató alapiskolai tanulók aránya tág határok közt ingadozik, sokkal magasabb a nagyobb településeken és az elővárosi térségekben, mint másutt (OECD 2015).

Ball és Youdell (2008) exogén és endogén privatizációfogalmára építve Lundabl és szerzőtársai (2013) megkülönböztetik egymástól az ún. belső és külső privatizációt. Ugyancsak használják emellett a belső és külső piacosítás fogalmát. A szerzők belső vagy rejtett privatizáció alatt azt a már a hetvenes évek végén elkezdődött, a nyolcvanas évek végén, illetve a kilencvenes évek elején kiteljesedő folyamatot értik, amelyben a korábban központosított döntési hatásköröket fokozatosan helyi szintre helyezték át, és amelyben a korábbi, szabályok alapján történő oktatásirányítást a mutatók, célok és eredmények alapján történő irányítás váltotta fel. E folyamat során a fogyasztói választásról szóló neoliberális diskurzus vált uralkodóvá, és felerősödött az ún. állami monopólium megtörésének igénye. Ennek alapján állítja Lundabl (2002), hogy a decentralizáció folyamata taposta ki a később bekövetkező külső privatizációhoz, az oktatási utalványok és a kvázipiacok felhasználásához vezető utat.

Ezzel párhuzamosan az NPM-re épülő stratégiák szelleme mind jobban meghatározta a svéd iskolákban folyó munkát (a szerzők álláspontja szerint egyébként más országokban is tapasztalhatók hasonló tendenciák), és ennek eredményeképp az iskolák félig autonóm, eredményvezérelt gazdasági egységekké alakultak át. „Az oktatás fokozatosan szigorú vizsgálatnak és értékelésnek lett alávetve annak biztosítása érdekében, hogy az iskolák megfelelően magas szinten »teljesítsenek«, »termeljenek« vagy »szolgáltassanak«", és az erőforrás-allokációs, költségvetési, tervezési és személyzeti döntések terén egyre inkább autonómmá váló ,igazgatók ennek megfelelően pedagógiai vezetői szerep helyett már mindinkább menedzseri szerepet töltöttek be" (Lundabl et al. 2013: 503).

Bár a tiszta magánszolgáltatás keretében nyújtott, a felhasználó által fizetett, valódi piaci oktatási szolgáltatások (pl. házifeladatok elkészítését vállaló magánszolgáltatók szolgáltatásai) igénybevétele egyelőre viszonylag kevéssé terjedt el Svédországban, a teljesen közösségileg finanszírozott, de magánszolgáltatók (független vagy szabad iskolák) által nyújtott oktatási kvázipiac virágzásnak indult azzal párhuzamosan, ahogy a szabad fogyasztói választás mind nagyobb szerepet kapott az oktatásban a kilencvenes évek folyamán. Ezt a folyamatot Lundabl és szerzötársai (2013) külsö piacositásnak is nevezik.

\section{A szabad iskolaválasztás és a kvázipiaci reformok megítélése}

A szabad iskolaválasztás jogára épülő oktatási piacosítást (pontosabban kvázipiacosítást), valamint a tanulókért folyó iskolák közötti versenyt előmozdító svéd reformok hatásának megítélése ellentmondásos. A rendszer bevezetése, majd fenntartása mellett érvelő politikusok, vagy azok, akik filozófiai megfontolásokból támogatják a nagyobb választá- 
si szabadságot, általában azzal érvelnek, hogy a tanulókért (és a velük járó forrásokért) folyatatott verseny ösztönzi az iskolákat az oktatás minőségének javítására és a lakossági igények jobb kielégítésére. A rendszer kritikusai pedig általában attól tartanak, hogy a szabad iskolaválasztás következményeképp az oktatás egységes színvonalának célja jelentéktelenné válik, és erősödik a társadalmi szegregáció (Kilimci-Riis 2008; Wiborg 2010; Magnússon 2019).

Míg Sablgren (2010) inkább a pozitív hatásokat hangsúlyozza, az OECD (2015) jóval szkeptikusabb, rámutatva arra, hogy a szabad iskolaválasztás lehetővé tételét követő évtizedben a PISA-eredmények szerint a svéd iskolák közti különbségek felerősödtek, nőttek. Ugyanakkor arra is felhívja a figyelmet, hogy az adatok nem alkalmasak arra, hogy segítségükkel oksági összefüggést igazoljunk. Az mindenesetre az egész decentralizációs, privatizációs, „neoliberális” oktatási reform sikerességét megkérdőjelezheti, hogy míg a reform előtt PISA-eredményeit tekintve Svédország kismértékben még az OECD-átlag felett volt, mostanra jóval átlag alatti helyzetbe került. „Nincs a PISAvizsgálatban részt vevő egyetlen másik ország sem, melyben az elmúlt évtizedben az eredmények meredekebben estek volna, mint Svédországban." (OECD 2015: 27.) Ez akkor is elgondolkodtató, ha oksági kapcsolat nem is mutatható ki a reform és az eredmények romlása között.

Wiborg (2010) abból a szempontból vizsgálta a svédországi szabad iskolaválasztás és a független magániskolák elterjedésének hatásait, hogy ezekből milyen tanulságok vonhatók le más országok (pl. Nagy-Britannia) számára. Megállapítja, hogy a svéd szabad iskolaválasztás sajátossága, hogy bár az oktatási utalványok és az iskolák közti verseny deregulációt vitt a rendszerbe, a központi kormányzati és a helyhatósági felelősség és kontroll erős maradt a pénzügyi forrásokhoz való hozzáférés terén, illetve a nemzeti tanterven és a tanfelügyeleten keresztül. A korábbi svéd jóléti rendszert, amely a közösségi szektor által elöállított univerzális szolgáltatásokat egy bürokratikus tervezési rendszerben allokálta, egy olyan rendszer váltotta fel, melyben a szolgáltatások igénybe vevőinek választásai sokkal nagyobb szerepet játszanak. Ez társadalmilag rétegződött szolgáltatás-fogyasztási mintázatokhoz vezetett. A közös komprehenzív iskola azonban túlélte ezeket a változásokat, hiszen a tanulók ma sincsenek alapvetően képesség szerint szétválasztva, a magániskolákban tanulók aránya a növekedés ellenére relatíve még mindig nem magas, és a tanulói teljesítmények tekintetében az iskolák közti szóródás relatíve ma is nagyon alacsony.

Ugyanakkor az utalványreform amellett, hogy megnyitotta a magánszolgáltatók számára az oktatási piacot, az önkormányzati iskolákra is nagy hatással volt. A forrásokért folyó verseny és a szabad szülői választás együttesen az önkormányzati szektoron belül is erősítette a szegregációt és növelte az iskolák közti különbségeket: a népszerü iskolákba megugrottak a jelentkezések, mások pedig elnéptelenedtek. Egyes iskolák elitiskolákká váltak, mások pedig rossz hírnévre tettek szert. Mindez megmutatta, hogy nemcsak a lakóhelyi szegregáció okozhat oktatási szegregációt, de a szülői választás is hozzájárulhat a szegregáció növekedéséhez. (Példa lehet erre, ha egyes szülők nem akarják, hogy gyermekeik olyan iskolába járjanak, melyben nagy arányban találhatók bevándorló 
családok svédül gyengébben beszélő gyerekei, és ezért olyan iskolát választanak nekik, ahol nagyon kevés a nem svéd anyanyelvü gyermek. $)^{3}$

Fjellman, Hansen és Beach (2018) a felső középiskolás diákok ingázásának hatásait vizsgálja 1997 és 2011 között. Azt találták, hogy a földrajzi és demográfiai adottságokból fakadó különbségek a szabad iskolaválasztást lehetővé tevő reform hatására felerősödtek. Több diák és nagyobb távolságokra ingázik, és a középiskolák között nagyon jelentősen megnőtt a magániskolák aránya. A ritkán lakott területeken csökkent az állami középiskolák száma, miközben ez a folyamat az ilyen területeken nem járt a magán-középiskolák számának növekedésével, azaz az ilyen területeken csökkent a helyi választék. Ez gyakorlatilag a nem nagyvárosi fiatalok közül sokak számára lehetetlenné teszi, hogy élhessenek az iskolaválasztás szabadságával. A központi körzetekben (Stockholm és más nagyvárosok) ugyanakkor sok új iskola nyílt, nőtt a választék. Ezek a tapasztalatok arra mutatnak, hogy a társadalmi rétegződés piaci mechanizmusok segítségével történő csökkentésére vonatkozó kormányzati szándékok nem valósultak meg.

Magnússon (2019) az SNI-s gyerekek helyzete szempontjából vizsgálja a szabad iskolaválasztás svédországi bevezetésének hatásait. Ennek kapcsán áttekinti a rendelkezésre álló szakirodalmat, és nagyon sok hivatkozás alapján arra a végkövetkeztetésre jut, hogy a szabad iskolaválasztás elterjedése és az oktatási rendszeren belüli egyenlőség csökkenése, valamint a társadalmi szegregáció erősödése közötti korreláció ténye jól meglapozott, nem vitatható (Magnússon 2019: 4). Az iskolák egyre szegregáltabbakká válnak mind etnikai szempontból, mind pedig a szülők társadalmi háttere szerint. A felsőfokú végzettségü szülők gyerekei felül vannak reprezentálva a független iskolákban. A független iskolák tanulóinak teljesítménye valamivel jobb, mint az önkormányzati iskolák tanulóié, de ez részben a társadalmi-gazdasági háttér különbségeire és a társadalmi helyzet alapján történő szelekcióra vezethető vissza.

\section{Átalakulóban az észak-európai oktatási modell}

Antikainen (2006) cikke, valamint a Blossing-Imsen-Moos-kötet (2014) egyaránt rámutatnak arra, hogy az északi országok oktatási rendszereiben az oktatás magas színvonala és viszonylagos egyenlősége arra a közös, a térség egészére kiterjedő sajátosságra épült, hogy 16 éves korukig a különféle hátterü, képességü és érdeklődésű tanulók együtt tanultak egy egységes, nem szelektív komprehenzív iskolában, lehetőség szerint otthonukhoz közel. Ezekben az inkluzív iskolákban az alacsony iskolai teljesítmény elkerülését szolgáló oktatási módszerek lehetővé tették a speciális nevelési igényü vagy a kedvezőtlen szociális hátterü tanulók integrációját. Ez a modell emellett nagy súlyt fektetett az egyes iskolák megközelítően azonos színvonalának biztosítására is.

Ez a skandináv oktatási modell az észak-európai jóléti államok olyan közös alapelveire épült, mint a méltányosság, igazságosság és a részvétel. Antikainen (2006) kiemeli emellett a skandináv munkaerőpiaci modell és a tartós gazdasági növekedés fontos szerepét is ennek az oktatási modellnek a fennmaradásában.

Ha még egy ilyen, a bevándorlókkal szemben kevéssé előítéletes, befogadó attitűdű országban, melyben az univerzalisztikus svéd jóléti állam müködésének betudhatóan a társadalmi egyenlőtlenség viszonylag alacsony, is elöállhat egy ilyen, a szegregáció erősbödéséhez vezető helyzet, képzelhetjük, az oktatási egyenlőtlenség milyen erős növekedéséhez vezethetne a szülői választásra épülő oktatási szegregáció másutt, más körülmények között. 
A cikkben korábban részletezett svédországi változásokhoz igen hasonló folyamatok mentek végbe a többi észak-európai ország oktatási rendszerében is, még ha a kiinduló helyzet nem jelentéktelen országonkénti eltéréseire tekintettel e változások részleteiket tekintve némileg különböztek is. Møller (2008) felhívja a figyelmet arra, hogy a közelmúltbeli észak-európai oktatási reformokat bemutató irodalmak tanúsága szerint a korábban egységes, a komprehenzív iskolára épülő skandináv oktatási modellt erősen kikezdte a neoliberalizmus nemzetközi erősödése. Erre utal a Blossing-Imsen-Mooskötet (2014) alcíme is. Az észak-európai jóléti államok egyik alappillérét alkotó egységes közös iskola meggyengült, ahogy a közösségi oktatás rendszerét mindinkább felváltotta a kvázipiaci modell.

Dovemark és szerzőtársai (2018) hangsúlyozzák, hogy az 1980-as évektől mind több országban megjelenő, a közösségi szektort érintő neoliberális, NPM-re támaszkodó reformok három fö vezérlő elve a dereguláció, a privatizáció és a piacosítás (marketizáció) volt világszerte. Ennek a három vezérelvnek a hatását érhetjük tetten az észak-európai oktatási rendszerek reformkísérleteinek vizsgálata során is. A dereguláció a reformok első hulláma során a kilencvenes években elsősorban abban nyilvánult meg Észak-Európában, hogy a korábban erősen centralizált oktatási rendszereket decentralizálták, jelentősen megnövelve az önkormányzati szolgáltatók szerepét. A kétezres évek elején tetőző második hullám már elsősorban a privatizációra és a piacosításra támaszkodott: ennek során iskolapiacot (pontosabban inkább valamiféle kvázipiacot) próbáltak meg létrehozni, eltérő profilt adva a korábban meglehetősen egyforma iskoláknak, kihasználva a privatizációban és a szabad iskolaválasztásban rejlő lehetőségeket. Ennek a folyamatnak a során az állam korábbi fenntartói/szolgáltatói szerepéből fokozatosan elmozdult az oktatási szabályozás megalkotója és kikényszerítője szerepébe.

\section{Köszönetnyilvánítás}

A cikk alapjául szolgáló kutatást a 124867 sz. OTKA projekt (2017-2020) támogatta. A szerző köszönetet mond Le Marcellnek az irodalomfeldolgozáshoz nyújtott segítségéért és a cikk egy korábbi változatához füzött hasznos megjegyzéseiért.

\section{IRODALOM}

Ahrin, Å. \& Mörk, E. (2007) Effects of Decentralization on School Resources: Sweden, 1989-2002. Department of Economics Working paper 2007/9, Uppsala University.

Antikainen, A. (2006) In Search of the Nordic Model in Education. Scandinavian Journal of Educational Research, Vol. 50. No. 3. pp. 229-243.

Ball, S. J. \& Youdell, D. (2008) Hidden Privatisation in Education. Brussels, Education International.

Björklund, A., Edin, P-A., Fredriksson, P. \& Krueger, A. (2004) Education, Equality and Efficiency - An analysis of Swedish School Reforms During the 1990s. Institute for Labour Market Policy Evaluation Report 2004/1.

Blanchenay, P., Burns, T. \& Koester, F. (2014) Shifting Responsibilities: 20 years of Education Devolution in Sweden: A Governing Complex Education Systems Case Study. OECD Education Working Paper, 104. 
Blossing, U., Imsen, G. \& Moos, L. (2014, eds) The Nordic Education Model. 'A School for All' Encounters Neo-Liberal Policy. New York, Springer.

Blossing, U. \& Söderström, Å. (2014) A School for Every Child in Sweden. In: U. Blossing, G. Imsen \& L. Moos (eds) The Nordic Education Model. 'A School for All' Encounters Neo-Liberal Policy. New York, Springer. pp. 17-34.

Daun, H. (2002) Conceptualization and Results of Educational Restructuring. In: H. Daun (ed.) Educational restructuring in the Context of Globalization and National Policy. New York \& London, Routledge Falmer. pp. 71-114.

Dovemark, H., Kosunen, S., Kauko, J., Magnúsdóttir, B., Hansen, P. \& RasmusSEN, P. (2018) Deregulation, Privatisation and Marketisation of Nordic Comprehensive Education: Social Changes Reflected in Schooling. Education Inquiry, Vol. 9. No. 1. pp. 122-141.

Edmark, K., Frölich, M. \& Wondratschek, V. (2014) Sweden's School Choice Reform and Equality of Opportunity. IFAU Working Paper Series, 16. https://www.ifau.se/ globalassets/pdf/se/2014/wp2014-16-swedens-school-choice-reform-and-equality-ofopportunity.pdf

Erikson, R. \& Jonsson, J. O. (1996) The Swedish Context: Educational Reform and Long-term Change in Educational Inequality. In: R. Erikson \& J. O. Jonsson (eds) Can Education Be Equalized? The Swedish Case in Comparative Perspective. Boulder, Westview Press.

Eurydice (2018) Sweden: Single Structure Education (Integrated Primary and Lower Secondary Education). https://eacea.ec.europa.eu/national-policies/eurydice/content/singlestructure-education-integrated-primary-and-lower-secondary-education-36_en [Letöltve: 2019. 06. 01.]

Fjellman, A-M., Hansen, K. Y. \& Beach, D. (2018) School Choice and Implications for Equity: The New Political Geography of the Swedish Upper Secondary School Market. Educational Review, Vol. 71. No. 4. pp. 518-539.

Green, A. (1997a) Education, Globalization and the Nation State. London, Macmillan.

Green, A. (1997b) Educational Achievement in Centralized and Decentralized Systems. In: A. H. Halsey et al. (eds) Education: Culture, Economy, and Society. Oxford, Oxford University Press. pp. 283-298.

Halldén, K. (2008) The Swedish Educational System and the ISCED-97. In: S. L. SchneIder (ed.) The International Standard of Classification of Education (ISCED-97): An Evaluation of Content and Criterion Validity in 15 European Countries. Mannheim, MZES. pp. 253-267.

Kádárné Fülöp J. (1991) A svéd tanügyigazgatás mai képe. Magyar Pedagógia, Vol. 91. Nos. 3-4. pp. 171-185.

Kilimci, S. \& Rirs, U. (2008) Educational System in Sweden: Trends and Reforms. Sosyal Bilimler Enstitüsü Dergisi, Vol. 17. No. 2. pp. 255-266.

Laegreid, P., Roness, P. G. \& Rubecksen, K. (2008) Controlling Regulatory Agencies. Scandinavian Political Studies, Vol. 31. No. 1. pp. 1-26.

Lundahl, L. (2002) From Centralisation to Decentralisation: Governance of Education in Sweden. European Educational Research Journal, Vol. 1. No. 4. pp. 625-636.

Lundahl, L., Arreman, I. E., Holm, A-S. \& Lundstörm, U. (2013) Educational Marketization the Swedish Way. Educational Inquiry, Vol. 4. No. 3. pp. 497-514.

Magnússon, G. (2019) Inclusive Education and School Choice Lessons from Sweden. European Journal of Special Needs Education. https://doi.org/10.1080/08856257.2019.160 3601 [Letöltve: 2019. 05. 10.] 
Møller, J. (2008) Scandinavian Approaches to School Leadership. http://www.oecd.org/ education/school/40553301.pdf [Letöltve: 2019. 06. 01.]

Nilsson Lindström, M. \& Beach, D. (2015) Changes in Teacher Education in Sweden in The Neo-liberal Education Age: Toward an Occupation in Itself or a Profession for Itself? Education Inquiry, Vol. 6. No. 3. pp. 241-258.

OECD (2015) Improving Schools in Sweden: An OECD Perspective. Paris, OECD.

OECD (2017) Education Policy Outlook: Sweden. Paris, OECD.

Olofsson, J. (2005) Svensk Yrkesutbildning. Vägval i Internationell Belysning. Stockholm, SNS Förlag.

Pareliussen, J. (2019) Sweden's Schools: Lessons from History to Build a Better Future. https://oecdecoscope.blog/2019/03/29/swedens-schools-lessons-from-hitroy-to-build-abetter-future [Letöltve: 2019.06.01.]

Pollitt, C. \& Bouckaert, G. (2011) Public Management Reform. A Comparative Analysis: New Public Management, Governance, and the Neo-Weberian State. Oxford, Oxford University Press.

Rönnberg, L. (2014) School Inspection in Sweden: Historical Evolution, Resurrection and Gradual Change. Revue française de pédagogie, Vol. 186. (janvier-février-mars) pp. 35-45.

Sahlgren, G. (2010) Schooling for Money: Swedish Education Reform and the Role of the Profit Motive. IEA Discussion Paper No. 33.

Szala Í Ás (2002) Fiskális föderalizmus. Áttekintés. Közgazdasági Szemle, XLIX. évf., május (424-440. o.)

Wiborg, S. (2010) Swedish Free Schools: Do They Work? London, LLAKES Centre Institute of Education.

A cikk a Creative Commons Attribution 4.0 International License (https://creativecommons.org/licenses/ by/4.0/) feltételei szerint publikált Open Access közlemény, melynek szellemében a cikk bármilyen médiumban szabadon felhasználható, megosztható és újraközölhető, feltéve, hogy az eredeti szerző és a közlés helye, illetve a CC License linkje és az esetlegesen végrehajtott módosítások feltüntetésre kerülnek. (SID_1) 